\title{
Romantic Nationalism: History and Illusion in Ireland ${ }^{1}$
}

\begin{abstract}
$\underline{\text { Abstract }}$
Intellectual historians often invoke "romanticism" to account for the origins and conceptual shape of nationalism. In an Irish context, however, this approach has yielded false genealogies of influence and an impaired political understanding. Cast through a "romantic" prism, nationalism is divorced from its conditions of intelligibility, becoming unhelpfully isolated from questions about sovereignty, democratic legitimacy and the nature of modern citizenship. Thus all too often the irrationality that is made part of the definition of "romantic nationalism" is a function of the way that it is interpreted.
\end{abstract}

\footnotetext{
${ }^{1}$ I am grateful to Roy Foster, Chris Insole, Duncan Kelly and the anonymous reviewers for their careful scrutiny of this article.
} 


\section{Romantic Nationalism: History and Illusion in Ireland}

Nationalism has long been viewed as a "romantic" ethos though this description has meant many things. It has functioned as a strong evaluation - with the "romantic" operating both as a term of abuse and approval - but it has also served in a more technical capacity, playing a key part in a broader explanation of nationalism. ${ }^{2}$ So the origins of the credo, or at least a strand of it, are traced to a romantic period or ideology or some combination of these. The term "romantic nationalism" is thus ubiquitous in modern scholarship. ${ }^{3}$ The category usually stands for a subset of nationalism, although it can also function as a tautology,

2 See, for instance, Hans Kohn, The Idea of Nationalism: A Study of its Origins and Background (New Brunswick, 2005), 349-93; Elie Kedourie, Nationalism (London, 1960), 87; Jacob Talmon Political Messianism: The Romantic Phase (London, 1960); Tom Nairn, The Break-Up of Britain: Crisis and Neo-Nationalism, rev. edn. (London, 1981), 340; Anthony D. Smith, Nationalism and Modernism (London, 1998), 51-53; Adam Zamoyski, Holy Madness: Romantics, Patriots and Revolutionaries (London, 2001); Joep Leerssen, National Thought in Europe: A Cultural History (Amsterdam, 2006); Michal Kopeck, Balazs Trencsenyi (eds.), National Romanticism: The Formation of National Identity in Europe (Budapest, 2007).

3 For overviews and definitions of "romantic nationalism," see J. C. Eade (ed.), Romantic Nationalism in Europe (Canberra, 1983); Joep Leerssen, "Notes towards a Definition of Romantic Nationalism," Romantik: Journal for the Study of Romanticisms, 2.1 (2013), 9-35; idem., 'What was Romantic Nationalism? The Onset, The Long Tail, the Banal', NISE, 2 (2014), 5-44. 
since all nationalisms have been presented as instances of "political romanticism". ${ }^{4}$ However, this essay questions the usefulness of "romanticism" as an explanatory concept in the context of nationalism - in particular, Irish nationalism. The evaluative properties of the term - the "romantic" has signified the atavistic, the emotive and the fanciful since the eighteenth century - can certainly be summoned to describe advocates of nationalism or, indeed, enthusiasts of any political position. ${ }^{5}$ But these are coarse evaluations at best and do little to account for the content or basic intentionality of nationalist belief. The use of "romanticism" - as an ideological matrix or looser collection of vocabularies - to map the provenance or conceptual shape of such belief has fared little better. Cast through a romantic prism, nationalism, I argue, loses its political intelligibility and becomes oddly divorced from questions about sovereignty, democratic legitimacy and the nature of modern citizenship.

This transcendence of politics partly stems from the fact that romanticism is usually deemed to be a cultural formation - one, moreover, in which the aesthetic is sometimes judged to reign supreme over all other values. ${ }^{6}$ If this appears to make political commitments secondary, then nationalism - that is to

\footnotetext{
${ }^{4}$ According to Isaiah Berlin, nationalism per se was a species of "political romanticism". See Isaiah Berlin, Against the Current, ed. Henry Hardy, 2nd edn. (Princeton, 2013), 349.

5 Samuel Johnson lists the following definitions of the "romantick": "1. Resembling the tales of romances; wild 2. Improbable; false 3. Fanciful; full of wild scenery". Samuel Johnson, $A$ Dictionary of the English Language, 6 ${ }^{\text {th }}$ edn. (London, 1785).

6 Isaiah Berlin, The Roots of Romanticism (Princeton, 1999), 168. See too Ozit Özkirimli, Theories of Nationalism: a Critical Introduction, $2^{\text {nd }}$ ed. (Basinstoke, 2010), 16.
} 
say "political romanticism" - is a curiously self-contradictory form of politics. ${ }^{7}$ The insistent twinning of romanticism and nationalism also rests on perceptions of both as species of irrationalism. ${ }^{8}$ Over recent decades scholars have produced much more sophisticated accounts of each phenomenon; nonetheless, even in the most current scholarship, both appear as forms of counter-enlightenment, deeply suspicious if not hostile to reason. ${ }^{9}$ The standards of rationality that have traditionally shaped these evaluations are rarely made explicit. It is easily shown that nationalism houses factually inaccurate beliefs - Ernest Renan's claim that getting history wrong is basic to nations is now conventional academic wisdom. ${ }^{10}$ However, it is hard to see how this exhausts the question of

7 For an early account of this anti-political politics, see Carl Schmitt, Political Romanticism, trans. Guy Oakes (New Brunswick, 2011), 146.

8 For debate about the rationality of nationalism, see Albert Breton et al. (eds.), Nationalism and Rationality (Cambridge, 1995); Michael Hechter, "Nationalism and Rationality," Journal of World Systems Research, 6 (2000), 308-29; Dusan Kecmanovic, "The Rational and the Irrational in Nationalism," Studies in Ethnicity and Nationalism, 5.1 (2005), 2-26.

9 For accounts of this irrationalism in an Irish context, see Tom Garvin, Nationalist Revolutionaries (Oxford, 1984), 24, 174; Seán McConville, Irish Political Prisoners, 1920-1962 (London, 2003), 7; Richard English, Irish Freedom (London, 2008), 158; James Dingley, The IRA: The Irish Republican Army (Santa Barbara, 2012), ix-x; idem., Durkheim and National Identity in Ireland (London, 2015); Bryan Fanning, Histories of the Irish Future (London, 2015), 234.

10 See Ernest Renan, “Qu'est-ce qu'une nation?” (1882), in Oeuvres complètes de Ernest Renan, ed. Henriette Psichari, 10 vols. (Paris, 1947), 1: 887-907, at 902. On nationalist myth-making see, Eric Hobsbawm, Nations and Nationalism since 1780, 2nd edn. (Cambridge, 1992), 12-13; Arash Abizadeh, "Historical Truth, National Myths and Liberal Democracy: On the Coherence of Liberal Nationalism," The Journal of Political Philosophy, 12.3 (2004), 291-313. 
nationalism's rationality. ${ }^{11}$ Further assumptions about rational motivation organised around an ancient contest of the faculties play a role here: the apparent exaltation of essentially non-cognitive passions under romantic nationalism leads, it seems, to the eclipse of reason. Moreover, nationalists and romantics fail to meet - or openly defy - basic criteria of rational self-interest (which sometimes seems to be identified with rationality per se). Thus, the apparent cult of self-sacrifice under romanticism and nationalism is evidence of their extreme irrationalism. People, we learn, "do not voluntarily die for things that are rational". 12

Ireland, it would seem, has had no dearth of irrational volunteers and the reasons for this have been attributed to the dangerous efficacy of romantic nationalism in the country. ${ }^{13}$ Theories of rational action are inevitably circular, but accounts of romantic nationalism, I shall argue, draw the circle very tightly indeed, often converting it into an irrational force before analysis of its content has really begun. Conor Cruise O'Brien, a self-conscious "child of the Enlightenment", was one of the most formidable and influential antagonists of this irrationalism in Ireland. ${ }^{14}$ Throughout the 1970s and 1980s 0'Brien roundly

11 As Skinner argues, it is a mistake to equate "false beliefs with lapses of rationality". Quentin Skinner, Visions of Politics. Volume 1: Regarding Method (Cambridge, 2002), 33.

12 Walker Connor, Ethnonationalism: The Quest for Understanding (Princeton, 1994), 206.

13 See Seán Farrell Moran, "Patrick Pearse and the European Revolt against Reason," Journal of the History of Ideas, 50.4 (1989), 625-43; Richard English, Ernie O'Malley: IRA Intellectual (Oxford, 1998), 117; English, Irish Freedom, 303.

${ }^{14}$ Conor Cruise O’Brien, On the Eve of the Millennium: The Future of Democracy through an Age of Unreason (New York, 1994), 29. 
castigated both the emotive and romantic character of nationalism in a variety of intellectual forums. ${ }^{15}$ O'Brien wrote in a climate when romanticism was widely diagnosed as a species of counter-enlightenment, a position popularised by Isaiah Berlin - a correspondent and critical admirer of 0'Brien's. ${ }^{16}$ It was also the period in which the romantic credentials of nationalism were stressed by political theorists: Berlin did so in Oxford, Elie Kedourie made a similar case in the London School of Economics. O'Brien's account of nationalism - not least in his sense of its antiquity - differed from these influential thinkers, but he continued to present nationalism as something which becomes radicalised in the nineteenth century and quickly turns its back on the achievements of the enlightenment.

Similar, albeit less sweeping views would shape academic historiography in the same period. For some of Ireland's most brilliant revisionists, the historian's task was to contest the "romantic" distortions of the past that various

\footnotetext{
${ }^{15}$ Initially, nationalism was so emotive that it lacked the rational content to function even as an ideology. See Conor Cruise O’Brien, "Ireland: the Shirt of Nessus," New York Review of Books, 29.7 (April 1982), 30-33. However, O'Brien later distinguished between nationalism as an "ideology" and as a "collective emotional force". Conor Cruise O’Brien, God Land: Reflections on Religion and Nationalism (Cambridge, Mass., 1988), 1.

16 Some of their correspondence is published as an appendix to O'Brien's study of Burke. Conor Cruise O’Brien, The Great Melody: A Thematic Biography of Edmund Burke (Chicago, 1992), 60518. For Berlin's very mixed praise of O’Brien, see Isaiah Berlin, Affirming: Letters 1975-1997, ed. Henry Hardy \& Mark Pottle (London, 2015), 488.
} 
nationalisms had produced. ${ }^{17}$ Not all nationalism was twinned with romanticism: in the 1980s scholars such as Oliver MacDonagh attempted to discriminate between its "enlightened" and "romantic" manifestations - a distinction that remains very much operative in revisionist or "postrevisionist" historiography today, most consistently, perhaps, in the work of Richard English. ${ }^{18}$ But, as I shall argue, the contrast between romantic and enlightened political outlooks is often distorting.

My argument has three main stages. First, I shall suggest that the "romantic" is a vexed concept in Ireland, having been deployed in colonial and anti-colonial polemic since at least the late eighteenth century. Here the distinctive features of Irish politics were repeatedly attributed to the romantic disposition of its inhabitants. Later assessments of romantic nationalism superenvene upon these earlier accounts. The romantic properties of such politics are no longer cast as Irish traits (although there remain some striking exceptions to this rule), but reflect the influence of a pan-European movement known as "romanticism". Perhaps the most systematic advocate of this position is Joep Leerssen - whose ambitious research on "romantic nationalism" in a pan-European context

\footnotetext{
17 F. S. L. Lyons, Ireland Since the Famine (London, 1971), 681. For a committed account of revisionism as form of enlightenment and therefore the counterforce of romanticism, see Dingley, Durkheim and National Identity in Ireland, 124-5.

18 English, Irish Freedom, 158. See also Prager's juxtaposition of who "Irish-Enlightenment convictions" with "Gaelic Romantic thoughts and beliefs". Jeffrey Prager, Building Democracy in Ireland: Political Order and Cultural Integration in a Newly Independent Ireland (Cambridge, 1986). See, too, Dingley, Durkheim and National Identity in Ireland, 71.
} 
explicitly sets out to refine and to update the work of Hans Kohn and Isaiah Berlin. ${ }^{19}$ However, I argue that the doctrinal elements of romanticism - in so far as these can be disinterred - do little to explain nationalism as a political phenomenon. I make this case in the second section of the essay where I concentrate on the Young Irelanders of the 1840s - usually regarded as the most influential exponents, if not the inventors, of "romantic nationalism" in Ireland. ${ }^{20}$ The essay concludes with a brief section on the various obituaries produced for romantic nationalism in twentieth-century Ireland.

\section{Romantic Ireland: the Genealogy of a Discourse}

By the time Yeats wrote his famous lament for it in September 1913, "Romantic Ireland" was already a dead metaphor or near tautology. ${ }^{21}$ Nineteenth-century perceptions of Ireland as a romantic entity partly revolved around shared impressions of its uneven economic and social development, often

19 Leerssen, “Notes towards a Definition of Romantic Nationalism," 10.

20 Giovanni Costigan, “Romantic Nationalism: Ireland and Europe," Irish University Review, 3.2 (1973), 141-52; Sean Cronin, Irish Nationalism: A History of Its Roots and Ideology (London, 1980), 67; George Boyce, Nationalism in Ireland $3^{\text {rd }}$ ed. (London, 1995), 156; English, Irish Freedom, 141. Roy Foster also describes the Young Irelanders as "the first romantics", although this is merely an effort to foreground their importance for Yeats who saw himself as one of the last. See R. F. Foster, Words Alone: Yeats and his Inheritances (Oxford, 2011), 45-90.

${ }^{21}$ W. B. Yeats, “September 1913," in The Variorum Edition of the Poems of W. B. Yeats, ed. Peter Allt and Russell K. Alspach (New York, 1956), 289-90. 
communicating mixed views of these facts (in Trollope's An Eye for an Eye [1879], for instance, the "romantic" appears as a synonym for the "semibarbarous", but it is also another word for "something marvellous").22 Explanations of Irish backwardness seized on different reasons: it stemmed from botched conquest and the entrenchment of native savagery; it reflected English misrule or deliberate sabotage of Irish interests; it was the result of Protestant monopoly or "Popish barbarism". ${ }^{23}$ Be that as it may, aspects of Ireland's present could seem strangely out-of-date, at least when seen through "modern" eyes or through a teleological scheme of historical development. According to the lawyer and poet Samuel Ferguson, Ireland displayed the "characteristics of many epochs"; here "a historical journey of six centuries may be performed in a little more than twice as many miles". The time-travel could be disorientating but it gave the country an air of "practical romance."24

The everyday in Ireland could be poeticised, but commentators often chose to dwell on the practical horrors of its "semi-savage state", focussing on the country's poverty and violence. ${ }^{25}$ Ireland's history of republican militancy, agrarian unrest and sectarian tension had given it a reputation for violence, even though statistical evidence from the nineteenth century suggests that it was relatively peaceable by European standards. Still in 1868 - that is well before the land wars of the 1870 s and early 1880s - an Irish land agent would

\footnotetext{
${ }^{22}$ Anthony Trollope, An Eye for an Eye, 2 vols. (London, 1879), 2: 45.

${ }^{23}$ For "Popish barbarism," see Dublin University Magazine (Nov., 1835), 521.

${ }^{24}$ Dublin University Magazine (Dec., 1836), 658.

${ }^{25}$ William Carleton, Traits and Stories of the Irish Peasantry, $6^{\text {th }}$ ed., 2 vols. (London, 1865), 1: 421.
} 
confidently aver that Ireland possessed "a kind of poetic turbulence and almost romantic violence which [. . . ] could scarcely belong to real life in any other country in the world."26 So Irish social circumstances were presented as fantastic or "novel-like" - that is to say romantic - an impression repeatedly stressed by Irish writers to attest to the authenticity of their own fictions. For the novelist and Protestant divine, Charles Maturin, Ireland was "the only country on earth, where [...] the extremes of refinement and barbarism are united, and the most wild and incredible situations of romantic story are hourly passing before modern eyes". ${ }^{27}$ Here romance was real. Predictably, the enchantment of reality would generate its own reaction, producing a tradition of realist writing in Ireland that focussed on the more prosaic and often squalid reality lurking behind "romantic shadow". ${ }^{28}$

The lovers' quarrel between realism and romance in Ireland shaped much of its literature but it would also influence conceptions of its history. Throughout the nineteenth century the country's past was repeatedly cast as "more romantic than romance". ${ }^{29}$ But in the late eighteenth century figures like Edward Ledwich had already assumed a highly sceptical view of Ireland's "romantic history" - a phrase that could operate descriptively for its ancient past, but also as a pejorative account of its fabulous construction. "In this enlightened age," he

\footnotetext{
26 William Steuart Trench, Realities of Irish Life (London, 1868), viii-ix.

${ }^{27}$ Charles Maturin, The Milesian Chief, 4 vols. (London, 1812), 1: v.

${ }^{28}$ George Moore, Parnell and his Ireland, ed. Carla King (Dublin, 2004), 41.

29 See Thomas Darcy McGee, A Popular History of Ireland from the Earliest Period to the Emancipation of the Catholics, 2 vols. (Glasgow, 1869), 1: vi.
} 
argued, "it can require no apology for exposing this wild chaos of absurdity and fable". Barbarous peoples were incapable of distinguishing between fact and fiction and modern antiquarians merely perpetuated mental barbarism in their credulous response to bardic tales - the "licentious fancies [of] rude and ignorant ages". ${ }^{30}$ Ledwich's account of romantic fantasy was itself rather fantastical: romantic habits of delusion, he announced, had been introduced to Europe by Saracen Arabs and had been passed on to Irish bards through the mediation of Spain - a fairly circuitous geography of wrongheadedness. But already the "romantic" operated as an antonym for "enlightened" - even if much "romantic history" had attempted to attribute enlightenment to peoples formerly considered barbarous. ${ }^{31}$ Subsequent commentators resisted the "pestilential vapours of historical scepticism" in the name of "romantic history" and would enjoy considerable success. ${ }^{32}$

The conflation of fact and fiction, derided by Ledwich, would become for many observers a defining feature of "romantic nationalism" or indeed nationalism in general. ${ }^{33}$ As the word "romantic" implies, critics pointed to the essential literariness of nationalist belief either as a metaphor for their counter-factual

\footnotetext{
${ }^{30}$ Edward Ledwich, "Observations on the Romantic History of Ireland," in The Transactions of the Royal Irish Academy (1790-92), 3: part 3, 30.

${ }^{31}$ For an overview of Irish antiquarianism, see Clare O'Halloran, Golden Ages and Barbarous Nations: Antiquarian Debate and Cultural Politics in Ireland c. 1750-1800 (Cork, 2004).

32 M. McDermot, A New and Impartial History of Ireland from the Earliest Accounts to the Present Time, 4 vols. (London, 1823), 1: 42.

33 For the nationalist's conflation of "literature and life, dream and reality", see Kedourie, Nationalism, 80.
} 
nature or as a causal theory of their origins. The fiction of Sydney Owenson, for instance, was judged to have given "first form to the rhetoric of Irish nationalists". ${ }^{34}$ According to Leerssen, Owenson's Wild Irish Girl (1806) "made Ireland romantic" and supplied the inaugural discourse for a "Romantic politics". ${ }^{35}$ Owenson's text certainly abounds with prospects "wildly romantic beyond all description"; it invokes a "genuine" but "singularly romantic history"; and it repeatedly calls attention to the romance-like features of its own textual world. $^{36}$ The novel's heroine Glorvinia "is both natural and national" - a naturalisation of political identity often read as a defining gambit of romantic nationalism. ${ }^{37}$ Moreover, the sentimentalism that Matthew Arnold would later present as the defining feature of the "Celt" is firmly in place: "our national character", Owenson writes, "admits no medium in sentiment."38 Ireland consequently serves as a health-spa for the English "apathist" who has lost all feeling to polite refinement. In Maria Edgeworth, too, Ireland provides a cure for metropolitan ennui, although she takes considerable pains to stress the dangers

\footnotetext{
34 Thomas Flanagan, The Irish Novelists, 1800-1850 (New York, 1959), 71.

35 Joep Leerssen, "How the Wild Irish Girl made Ireland Romantic," Dutch Quarterly Review of Anglo-American Letters 18.3 (1988), 209-27.

${ }^{36}$ See Sydney Owenson, The Wild Irish Girl: A National Tale, ed. Claire Connolly and Stephen Copley (London, 2000), 146, 196.

37 ibid., 116. On the fusion of the nature and nationality under nationalism, see Conor Cruise O’Brien, Passion and Cunning (London, 1990), 255.

38 Owenson, The Wild Irish Girl, 71.
} 
of unregulated sentiment. ${ }^{39}$ Here the discourse of "Romantic Ireland" is clearly up and running, although its political influence remains far from obvious.

What is undeniable is that in the novels of Edgeworth and Owenson Ireland became a staging-ground for a debate about feeling that had raged since the French Revolution. Edmund Burke had famously defended the sentiments - "the true supporters of all liberal and manly morals" - from the brutal consequentialism of French revolutionaries. ${ }^{40}$ This defence of sentiment would be cast as a "romantic" gesture, but it was a fairly standard "enlightenment" refrain: Burke stressed - just as Hutcheson, Hume and Smith had done - that sentiment was a constitutive feature of moral rationality. Thus to cut loose from our feelings was to depart from morality itself. ${ }^{41}$ Nonetheless, figures like Mary Wollstonecraft castigated Burke's "mortal antipathy" to reason and his dangerous indulgence of emotion. ${ }^{42}$ Such sentimentalism, she averred, was "romantic", taking pains to define what she meant by the term: it signified "false, or rather, artificial, feeling." 43 Wollstonecraft ultimately traced this sham sentiment to Rousseau - the alleged source of a "romantic" revolution, according

\footnotetext{
${ }^{39}$ See, in particular, Maria Edgeworth, Ennui [1809], ed. Jane Desmarais et al., in The Novels and Selected Works of Maria Edgeworth, ed. Marilyn Butler et al. (London, 1999).

40 Edmund Burke, The Writings and Speeches of Edmund Burke. Volume VIII: The French Revolution, 1790-1794, ed. Paul Langford and L. G. Mitchell (Oxford, 1989), 137.

41 See David Dwan, "Edmund Burke and the Emotions," Journal of the History of Ideas, 72.4 (2011), 571-93.

42 Mary Wollstonecraft, The Political Writings of Mary Wollstonecraft, ed. Janet Todd (London, 1993), 8.

43 ibid., 29.
} 
to a host of subsequent interpreters. ${ }^{44}$ Ironically, Burke would take the same tack. Precisely because sentiment for Burke was so foundational to ethical life, Rousseau's re-education of the passions - whereby everything became "spurious, fictitious and false" - led to moral and political disaster across Europe. ${ }^{45}$

These different accounts of feeling - as wise, blind, false and politically dangerous - repeatedly feature in Irish romances of the period. Wild Irish girls delight in the "sentimental sorcery" of Rousseau. ${ }^{46}$ Wild Irish boys - at least in Maturin's fiction - are not so unbuttoned and tend to turn from Rousseau "in dread and disgust". ${ }^{47}$ Thus, figures like Maturin, seek to rein in the passions they indulge: those who would see "the ties of society dissolved before the breath of sentiment" are urged to read no further. ${ }^{48}$ And so readers read on. Even The Wild Irish Girl ends with a plea to moderate the "constitutional sensibility" of

\footnotetext{
${ }^{44}$ The classic example among Anglophone audiences is Irving Babbitt, Rousseau and Romanticism (Boston and New York, 1919). See also S. S. B Taylor, "Rousseau's Romanticism" in Reappraisals of Rousseau, ed. S. Harvey et al. (Manchester, 1980), 2-23; Maurice Cranston, The Romantic Movement (Oxford, 1994); Thomas McFarland, Romanticism and the Heritage of Rousseau (Oxford, 1995); Nicholas Dent, Rousseau (London, 2005), 224-27.

${ }^{45}$ Burke, Writings and Speeches, 8: 315.

${ }^{46}$ Wild Irish Girl, 143. Olivia in St. Clair is an even more passionate enthusiast of Rousseau than Glorvinia. See Sydney Owenson, St. Clair or the Heiress of St. Ormond, 2 vols. (London, 1803), 1: 177-84.

${ }^{47}$ Charles Maturin, The Wild Irish Boy, 3 vols. (London, 1808), 1: 262.

48 ibid., $2: 3$.
} 
Irish national character. ${ }^{49}$ Nevertheless, these unstable fictions - with their highly ambivalent portraits of the passions - did little to dislodge the stereotype of the emotionally incontinent Celt. So by the beginning of the nineteenth century many of the tropes later associated with romanticism (and with Rousseau) - extreme emotivism, an unruly imagination, and a fond attachment to pre-modern manners - had become installed as Irish traits. Trollope was not alone in thinking that "the Irish character is peculiarly fitted for romance."50 For these reasons, it was also a character ill-fitted for politics - or so commentators would claim. ${ }^{51}$

In 1844 as Daniel O'Connell's campaign for Repeal of the Union with Great Britain reached its apogee, an Irish émigré to London lamented the fact that Irish men and women were tragically susceptible to "the illusions of romantic, national pride" - a toxic self-love which spoiled the country's patriotism and gave it a fanatical quality. ${ }^{52}$ Irish character may have made it vulnerable to romantic pride, but evidence suggests that even in England patriotism - or a particular style of it - could be cast as a "romantic" predilection in an enlightened age. Joseph Addison complained, for instance, that traditional amor patria was

\footnotetext{
${ }^{49}$ Owenson, Wild Irish Girl, 242.

${ }^{50}$ Anthony Trollope, An Autobiography of Anthony Trollope (New York, 1883), 141.

${ }^{51}$ Arnold, for instance, found something "romantic" in Celtic sensibility, but this attribute made the Celt "ineffectual in politics." Matthew Arnold, On the Study of Celtic Literature (London, 1867), 109, 106.

52 Daniel Owen Madden, Ireland and its Rulers, 3 vols. (London, 1843-44), 3: 319.
} 
now being viewed as "chimerical" and "romantic". ${ }^{33}$ David Hume made the same complaint. ${ }^{54}$ These concerns seem to have been shaped by eighteenth-century debates about the fate of ancient civic values in a modern social setting with unreconstructed republicans being viewed as unhealthily addicted to the rude passions of a warlike state rather than the polite manners of a commercial age. ${ }^{55}$ Here, perhaps, early theories of rational self-interest also influenced impressions of "romantic" exorbitance. Addison's Spectator is alleged to have prioritised rational "interests" over rude passions and sponsored a polite form of whiggism that had "no need for [. . .] republican virtues."56 Yet Addison worried nonetheless that moderns tended to "ridicule everything as romantic that comes in competition with their present interest". ${ }^{57}$ Whatever one's position, the "romantic" seems to have had a particular saliency in debates about patriotism.

\footnotetext{
${ }^{53}$ Joseph Addison, The Works of the Late Right Honorable Joseph Addison, 4 vols. (London, 1761), $4: 347$.

${ }^{54}$ David Hume, Essays, Moral, Political and Literary (Indianapolis, 1987), 538.

${ }^{55}$ Lawrence E. Klein, "Liberty, Manners, and Politeness in Early Eighteenth-Century England," Historical Journal, 32 (1989), 583-605; Nicholas Phillipson, "Politeness and Politics in the Reigns of Anne and the Early Hanoverians," in Varieties of British Political Thought, 1500-1800, ed. J. G. A. Pocock (Cambridge, 1993), 211-45; Iain Hampsher-Monk, "From Virtue to Politeness," in Republicanism: A Shared European Heritage, ed. Martin van Gelderen and Quentin Skinner, 2 vols. (Cambridge, 2002), 2: 85-105.

56 J. G. A. Pocock, Virtue, Commerce and History (Cambridge, 1985), 237. For a complication of this view, see Markuu Peltonen, "Politeness and Whiggism, 1688-1732," The Historical Journal, 48 (2005), 391-414.

57 Joseph Addison, The Works of the Late Right Honorable Joseph Addison, 4 vols. (London, 1761), $4: 254$
} 
Ireland's apparent lack of economic development allowed some nineteenthcentury commentators to perceive the survival of political values that might be declared defunct in other environments. According to Yeats, for example, Ireland was "a poor nation with ancient courage, unblackened fields and a barbarous gift of self-sacrifice". ${ }^{58}$ The country might be presented as a Celtic Sparta in which the values of classical republicanism lived on, but it was also judged to house a moral code known as "chivalry" - or what was long identified as a "romantic system" of manners. $^{59}$ Indeed, according to the antiquarian Sylvester O'Halloran, chivalry had entrenched itself in Ireland long before its appearance in any other European country. ${ }^{60}$ Later, Matthew Arnold and Ernest Renan would also cast chivalry as a Celtic invention. ${ }^{61}$ Enlightened discussions of chivalry were interestingly ambivalent: though it was often viewed as a ridiculous code of honour derived primarily from romances (even O'Halloran could deem it "absurd"), it was also regarded as a civilising force, which helped to differentiate modern nations from rude states. ${ }^{62}$ According to Adam Ferguson, for instance, chivalry placed moral constraints on violence, its gallantry had a lasting impact

58 W. B. Yeats, The Collected Works of W. B. Yeats: Volume IV: Early Essays, ed. Richard J. Finneran and George Bornstein (New York, 2007), 182.

59 Adam Ferguson, Essay on the History of Civil Society, ed. Fania Oz-Salzberger (Cambridge, 1995), 192.

60 Sylvester O'Halloran, An Introduction to and History of Ireland, 3 vols. (Dublin, 1803), 1: 53, 368.

${ }^{61}$ Arnold, On the Study of Celtic Literature, 108; Ernest Renan, Poetry of the Celtic Races and Other Studies, trans. William H. Hutchinson (London, 1896), 30.

${ }^{62}$ See Ryu Susato, “The Idea of Chivalry in the Scottish Enlightenment: The Case of David Hume," Hume Studies 33.1 (2007), 155-78. 
on conversation and manners, and this form of politeness had even advanced the cause of commerce. ${ }^{63}$ Thus Burke's famous lament for a chivalric age in the Reflections was not a fond expression of atavism, it was a critique of those who would return us to savagery by forgetting that commerce itself was predicated on gallant manners. ${ }^{64}$ Nonetheless, he was mocked as a new Quixote and chivalry was increasingly seen as a moribund system. ${ }^{65}$

If the chivalric system seemed to operate still in Ireland - in 1824 Thomas Crofton Croker noted "the spirit of chivalry [.. .] still survives" - it did so as a selfconsciously anachronistic force. ${ }^{66}$ Unsurprisingly, the Gaelic Chieftain in The Wild Irish Girl is a heroic misfit in a modern context: the "romantic sense of honour which distinguishes his chivalrous character" is not long for this world. ${ }^{67}$ Nostalgia was thus a constitutive element of romantic honour and Thomas Moore has traditionally been regarded as its chief laureate. Moore was a considerably more interesting figure than his own brand of Celtic melancholia might sometimes suggest, but pugnacious works such as “Oh! For the Sword of Former Time!" or "Let Erin Remember the Days of Old" could be accommodated

\footnotetext{
${ }^{63}$ Ferguson, Essay on the History of Civil Society, 191.

${ }^{64}$ Burke, Writings and Speeches, 8: 127. See Richard Bourke, "Edmund Burke and Enlightenment Sociability: Justice, Honour and the Principles of Government," History of Political Thought, 21.4 (2000), 632-656, at 652.

65 See Frans De Bruyn, "Edmund Burke, the Political Quixote: Romance, Chivalry and the Political Imagination," Eighteenth-Century Fiction 16.4 (2004), 695-734.

66 Thomas Crofton Croker, Researches in the South of Ireland: Illustrative of the Scenery, Architecture and the Manners and Superstitions of the Peasantry (London, 1824), 18.

67 Owenson, Wild Irish Girl, 208.
} 
in English drawing rooms, partly because the anachronistic character of such patriotism is internally acknowledged by the songs themselves. ${ }^{68}$ The song "Tis Gone, and For Ever" captures the spirit of many of the melodies. ${ }^{69}$ In Hazlitt's eyes, Moore had emasculated politics by aestheticizing it, making "prettinesses pass for patriotism". ${ }^{0}$ However, this was the quality that made Moore so dangerous in the eyes of other critics: he made "rebellion quite romantic". Thus, "the gallows that once terminated each avenue of treason, rose gratefully wreathed with shamrocks, and shaded into a bower of bliss."71

This would become a much-rehearsed charge, literature from Moore to Yeats being cast as a dangerous stimulant, fuelling a type of romantic nationalism in which aesthetics and politics were fatally merged. Significantly, in the nineteenth century this aestheticization of politics was repeatedly attributed to Irish national character: imaginative, passionate and incorrigibly romantic. On a tour of Ireland in 1846, the M.P. Lord John Manners insisted that "the Irish temperament is essentially poetical" and warned that the legislator who overlooks this "physiological fact cannot fail to make egregious mistakes."72 According to this earnest Young Englander, Ireland's poetical disposition made it resistant to the ugly prose of political economy and hyper-rationalist schemes of social improvement. In the eyes of The Times, however, the romantic attributes

\footnotetext{
68 Thomas Moore, Irish Melodies (London, 1821), 180, 40.

69 ibid., 147.

70 Spirit of the Age or Contemporary Portraits (London, 1825), 456.

${ }^{71}$ Dublin University Magazine (Sept., 1835), 297.

${ }^{72}$ Lord John Manners, Notes of an Irish Tour in 1846 (Edinburgh, 1881), 50.
} 
of the Irish had seriously retarded social and economic progress: "The grand, romantic, and picturesque fire the Irish imagination, but it plunges restless in the harness of practical work."73 By 1880 Mr Punch could afford to smile at Irish aestheticism. "Romantic, imaginative Ireland does not need politicians to govern her. She prefers poets."74 The word romantic was thus applied to the aggressively counterfactual nature of Irish patriotism with The Times, for instance, dismissing the idea of a native parliament in Ireland as yet another "romantic" fantasy. ${ }^{75}$

Later assessments of Irish politics were less inclined to embed these romantic properties within a general racial theory; instead, romanticism as a cultural movement was called upon to account for the country's political proclivities. of course, romanticism was a fairly plastic entity and could be given different political and even ethnic inflections. According to Sydney Owenson (one of the first Irish users of the term), romanticism was essentially a liberal ethos: "wherever freedom waved its oriflamme, there, it fixed its standard". Owenson admitted that "romanticism" was a fairly recent coinage and denoted "a literary sect", but she also maintained that it was informed by a more comprehensive and ancient set of values. Drawing heavily, it would appear, on Madame de Staël, she explained how romanticism emerged "from the northern forests, rude and barbarous as the people to whom it belonged, and like them, it overran the polished feebleness and elegant corruption which no longer served the interests

\footnotetext{
73 The Times, 1 October 1849.

74 Punch, 22 May 1880.

75 The Times, 19 May 1848.
} 
or reflected the feelings of a new-modelled society."76 This type of genealogy owed much to earlier theories of Gothic independence, stretching back to Tacitus' Germania. Accounts of "Gothic" freedom were often broad enough to incorporate Tacitus's freedom-loving Celts as well as his Germans, but they could also make Celts and Goths into rivals (an opposition that would increasingly harden into Celts and Saxons throughout the nineteenth century). ${ }^{77}$ Thus a Gothic derivation of political liberty had contentious implications and easily suggested that Ireland's ancient political liberties were not a Celtic creation, but were the result of a later Gothic conquest. ${ }^{78}$ Owenson was aware of these debates but in 1830 she was entirely undaunted by them. Somehow, romanticism emerged from the northern forests and ends up humming "its Cronan on the banks of the Shannon". ${ }^{79}$ Romanticism also stood behind Magna Charta and the city-republics of Renaissance Italy; it was exiled from absolutist France, but returned after the great Revolution, receiving its constitutional form in the Charter of 1814.

Thus, for Owenson, romanticism was a diffuse but essentially progressive phenomenon, equally committed to individual liberty in the realms of politics and of art. Indeed, Owenson revelled in the fact that under its aegis "the

\footnotetext{
${ }^{76}$ Lady Morgan, France in 1829-30, 2 vols. (London, 1830), 1: 228.

77 Colin Kidd, British Identities Before Nationalism: Ethnicity and Nationhood in the Atlantic World, 1600-1800 (Cambridge, 1999), 211-61.

78 Clare O'Halloran, Golden Ages and Barbarous Nations: Antiquarian Debate and Cultural Politics in Ireland, c. 1750-1800 (Cork, 2005), 56-64.

${ }^{79}$ Morgan, France, 1: 236.
} 
litterateur and the politician are no longer distinct personages": it was a great boon to freedom. ${ }^{80}$ However, the romantic merger of art and politics would later be denounced as the precondition for fascism and for a particular tradition of paramilitary violence in Ireland. In this scholarship, romanticism - a heady blend of aestheticism, emotivism, and atavism - is far from progressive: it exalts "passion over reason", "emotion over critical intellect", and befuddles the political intelligence of its adherents. ${ }^{81}$ I now wish to explore how this view of romanticism has shaped historical accounts of the evolution of nationalism in Ireland. I will suggest that these perspectives generally repress the political content of the phenomenon they study, thus replicating the mystification they seek to describe.

\section{Romantic Nationalism}

Though much of Irish life was judged to have a "romantic" aspect, the origins of "romantic nationalism" as a systematic programme is frequently traced to a small cadre of journalists and poets, known as "Young Ireland" who wrote under the banner of The Nation newspaper in the 1840s. In Yeats's estimate, the group had converted a vague sense of national feeling into "a definite political

\footnotetext{
80 ibid., $1: 261$.

${ }^{81}$ See English, Ernie O'Malley, 117.
} 
philosophy".82 If Yeats exaggerated the ideological coherence and originality of Young Ireland, many historians have followed his example in viewing the group as instigators of something new - a distinctive form of nationalism. ${ }^{83}$ Moreover, the sources of this credo would be traced to a romantic revolution that had transformed nineteenth-century Europe. So Young Ireland's quarrels with Daniel O'Connell - ostensibly about the relative merits of secular education, as well as the moral legitimacy of physical force as a means to independence - were expressive of a profound "ideological bifurcation" between romantic and enlightened values. ${ }^{84}$ Here $0^{\prime}$ Connell featured as a man of enlightenment; the Young Irelanders, on the other hand, drank at the "well of Romanticism". 85 The dualisms that traditionally describe this epochal strife now find Irish expression. As romantics, Young Ireland exalt "the race rather than the person", "instinct and

82 W. B. Yeats, The Collected Works of W. B. Yeats. Volume X: Early Articles and Reviews, ed. John P. Frayne and Madeleine Marchaterre (New York, 2004), 326.

83 Costigan, "Romantic Nationalism: Ireland and Europe"; Cronin, Irish Nationalism, 67; Oliver MacDonagh, States of Mind (London, 1983), 76 "Ideas and Institutions," in A New History of Ireland. V: Ireland Under the Union, 1: 1801-70, ed. W. E. Vaughan (Oxford, 1989), 198; Boyce, Nationalism in Ireland, 156; R. V Comerford, Ireland: Inventing the Nation (London, 2003); English, Irish Freedom, 141.

84 MacDonagh, "Ideas and Institutions", 198. For a similar dichotomizing, see Maurice O'Connell, Daniel O'Connell (Dublin, 1990), 51; Sean McGraw and Kevin Whelan, “O'Connell in Comparative Perspective, 1800-50," Éire-Ireland, 40.1\&2 (2005), 60-89; Christine Kinealy, Repeal and Revolution in Ireland (Manchester, 2009), 30.

85 English, Irish Freedom, 158. 
emotion rather than reason" and pursue "cultural" rather than constitutional liberation. ${ }^{86}$

This dichotomous logic snags against some of the evidence. The darling of the Young Ireland movement, Thomas Davis, thought he was campaigning for an Ireland that was "free, rich, and rational" even though the romantic prototype dictates that he was an emotivist in principle and disposition. ${ }^{87}$ Consequently, considerable emphasis used to be placed on a journey Davis made to Germany in 1839, where he underwent an "evangelical-like conversion" to German romanticism. ${ }^{88}$ As Roy Foster has argued, no evidence of Davis's Prussian visit exists and the theory has been baldly denounced by one of his most recent biographers, yet historians still refer to his "German-influenced conception of nationality". ${ }^{89}$ Davis quoted on occasion from Lessing and Goethe and may have come under some German influence through the mediation of Thomas Carlyle whom, as Foster and others have shown, Young Ireland idolised. ${ }^{90}$ Mangan, moreover, was deeply interested in German letters, although he tended to air these enthusiasms in the remarkably Teutonic Dublin University Magazine rather than the Nation. While over eighty references to German culture can be traced to

\footnotetext{
${ }^{86}$ MacDonagh, "Ideas and Institutions," 198.

87 Thomas Davis, Essays Literary and Historical, ed. D. J. O’Donoghue (Dundalk, 1914), 384.

88 MacDonagh, “Ideas and Institutions," 198; idem., The Emancipist: Daniel O'Connell, 1830-47

(London, 1989), 28. See too, Hutchinson, The Dynamics of Cultural Nationalism, 97.

89 Roy Foster, Modern Ireland, 1600-1972 (London, 1988), 311. John N. Molony, A Soul Came Into Ireland: Thomas Davis 1814-15 (Dublin, 1995), 25. English, Irish Freedom, 157.

90 See Foster, Words Alone, 45-50.
} 
the Nation between 1842 and 1848, this is considerably outweighed by the paper's commentary on French affairs. ${ }^{91}$ Nonetheless, Richard English still speaks of "Young Ireland's German-style Romantic nationalism”, while Leerssen maintains that the "Herderian-cum-Hegelian pattern of ethnic nationalism is firmly entrenched in Irish politics from the Nation onwards".92 But as a characterisation of nationalism, Leerssen's assertion is opaque (conflating, as it does, two very different thinkers); as a theory of influence, it lacks evidential grounds.

It is difficult to determine why the German provenance of Young Ireland's nationalism has been so insistently proposed. It may have something to do with the influential theory - ranging from De Staël to Isaiah Berlin - that romanticism arose in Germany and there would find "its truest home". ${ }^{93}$ The genealogy may be further informed by Berlin's contention that nationalism is a form of "political romanticism" and that its paradigmatic expression was German. ${ }^{94}$ But Berlin like Meinecke before him - also suggested that German nationalism began as a largely cultural phenomenon and it is in the fetishisation of culture as the basis of national unity that links between German and Irish nationalisms have been established; after all, the defining feature of "romantic nationalism", its theorists

\footnotetext{
${ }^{91}$ See Patrick O'Neill, Ireland and Germany: A Study of Literary Relations (New York, 1985), 10304.

92 English, Irish Freedom, 138. Joep Leerssen, Remembrance and Imagination: Patterns in the Historical and Literary Representation of Ireland in the Nineteenth Century (Cork, 1996), 22.

${ }^{93}$ Berlin, Roots of Romanticism, 152.

${ }_{94}$ Berlin, Against the Current, 346.
} 
allege, is that it "takes culture as its starting point".95 Thus, analogies between Herder's attempts to defend the homely virtues of Kultur against the universalistic pretentions of French civilisation and Young Ireland's desire to preserve an autochthonous culture from the empire of English ways bolster views of a causal connection. According to Conor Cruise O'Brien, cultural nationalism began with Herder in Germany, but "its ripples reached the shores of Ireland, around the middle of the nineteenth century", where it presumably found Young Ireland playing on the beach. ${ }^{96}$

The crude blend of politics and poetry that appeared in the Nation in the 1840 s may easily be viewed as a form of "cultural nationalism", although the novelty of the practice can also be overstated (in the 1790s the United Irishmen had attempted a very similar type of synthesis in the pages of the Northern Star). ${ }^{97}$ Moreover, the political logic behind Young Ireland's turn to "culture" is easily occluded by some of the strong contrasts that have been drawn between "cultural nationalism" and "political nationalism" or between "romantic"

\footnotetext{
95 Thomas Nipperdey, "In Search of Identity: Romantic Nationalism," in Romantic Nationalism in Europe, ed. J. C. Eade, 1-16, at 11.

${ }^{96}$ O’Brien, Passion and Cunning, 256. Though Young Ireland never made reference to Herder his importance to Young Ireland continues to be stressed. See Quinn, Young Ireland and the Writing of History, 40-41.

${ }^{97}$ See Tom Dunne, "Popular Ballads, Revolutionary Rhetoric and Politicisation," in Ireland and the French Revolution, ed. Hugh Gough and David Dickson (Dublin, 1990), 139-55; Mary Helen Thuente, The Harp Re-Strung: The United Irishmen and the Rise of Literary Nationalism (Syracuse,
} 1994). 
nationalism and nationalism proper. ${ }^{98}$ Young Ireland's cultural programme, however, had a profoundly political basis. It was, after all, a transparent bid to give historical substance to the idea of an independent people, although, as we shall see, it also reflected interesting anxieties about how sovereignty was to be conceived and legitimised. The group's stress on a common culture and history, moreover, was sold as a means to assuage sectarian tensions in Ireland. But the emphasis on the solidarity-giving effects of culture also expressed less predictable concerns about the fate of citizenship in a commercial and (as it appeared) increasingly democratic setting. Servicing these different ambitions was a stridently republican vision of politics. This republicanism was deeply derivative, but it gave a decisive inflection to the group's nationalism.

Basic to this republican vision, of course, was the idea of civic virtue. With unflagging zeal, the Nation called for civic activism and political friendship to defeat the dark armies of "corruption". ${ }^{99}$ Political evil was invariably traced to "the vile spirit of faction".100 However, when accused of being a faction themselves in their repeated spats with O'Connell, Young Ireland emphasised a more abrasive - or Machiavellian - strand of republican thought, stressing the civic value of internal dissension: it was "a safeguard against apathy and

\footnotetext{
98 For the separation of cultural nationalism from nationalism proper, see John Hutchinson, The Dynamics of Cultural Nationalism (London, 1987).

${ }^{99}$ For a fuller account of this republicanism, see David Dwan, The Great Community: Culture and Nationalism in Ireland (Dublin, 2008), chap. 2.

100 The Nation, 11 March 1848; The Nation, 20 June 1846.
} 
torpor".101 The Nation's indictments of individual and collective slavery were as republican as they were repetitive. The thinking here was that slaves and enslaved countries were abject not because they suffered, but because they were dependent on the "the leisure and the whim of another nation".102 A freedom enjoyed on sufferance was no freedom at all. Or as the Nation put it, "a good master is still a master, and we should be servants only to the Infallible."103 The ability to bear arms was the badge of the free citizen and the group furiously resisted governmental incursions on this "first right of man."104 Martial valour, for Young Ireland, was the apotheosis of citizenship - a position set out in articles such as "The Morality of War" and in reams of bellicose verse. It is easy to see why they would eventually split with O'Connell on the question of physical force.

Young Ireland often found it difficult to adapt their classical republican ideals to modern social circumstances - a situation which gave an anachronistic, impractical or "romantic" quality to the group's politics. But this "romanticism" is the result of a political vision; to see romantic ideology as its ground is to invert the causal picture. Young Ireland's republican commitments certainly calls into question some of the strong contrasts that have been drawn between an "enlightenment patriotism" committed to civic values and a "romantic

\footnotetext{
10113 April 1844.

102 ibid., 25 July 1846 [Nation's emphasis].

103 The Nation, 15 July 1848. For the neo-Roman background to his concept of liberty see, Quentin Skinner, Liberty before Liberalism (Cambridge, 1998), 1-57.

104 The Nation, 1 July 1843.
} 
nationalism" drawn to dubious theories of ethnic affiliation (a historical rationalisation of earlier attempts to distinguish between western and eastern, civic and ethnic, good and bad nationalisms). ${ }^{105}$ Such dichotomising overlooks Young Ireland's self-conscious attempts to model its politics on earlier patriot movements such as the Volunteers of the 1780s and the United Irishmen of the 1790s. Not only was the republican example of these patriots repeatedly extolled, the ecumenical ambition of the United Irishmen's patriotism, in particular, was warmly praised. Young Ireland had similar ambitions of uniting Protestants and Catholics under a common banner of Irishness. The "civic" or "ethnic" distribution of this Irishness was not, perhaps, fully clear. Davis professed to address the "Irish-born man", but he was also keen to insist that he heeded not "blood, nor creed, nor clan" once Ireland's cause was served. ${ }^{106}$ This may have provided little reassurance to those who shrank from the cause, but it was hardly a Celtic vision of Blutgemeinschaft. Indeed, when it came to politics, Davis was adamant, that one needed to abandon "distinctions of blood as well as sect". 107

105 See Leerssen, National Thought in Europe, 22, Leerssen, Remembrance and Imagination, 22. For a sceptical view of the theoretical viability of an ethnic-civic distinction, see Bernard Yack, "The Myth of the Civic Nation," Critical Review, 10.2 (1996), 193-211. On the untenability of the distinction in an Irish context see Matthew Kelly, "Languages of Radicalism, Race, and Religion in Irish Nationalism: The French Affinity, 1848-1871," Journal of British Studies, 49 (October 2010): 801-825.

106 Thomas Davis, The Poems of Thomas Davis (Dublin, 1846), 27-28.

107 Nation, 3 December 1842. 
Yet it would be naïve to insist on a seamless continuity between the civic republicanism of the 1790 s and the patriotisms of the 1840 s. If the United Irishmen drew much of their inspiration from the French Revolution of 1789, Young Ireland clearly modelled their own uprising in 1848 on the French example of that year. However, the group were initially ambivalent about France's revolutionary history, finding within it as much "madness" as they did virtue. ${ }^{108}$ Moreover, unlike the United Irishmen, they hesitated about adopting the "Rights of Man" as a legitimising discourse and shared widespread concerns (ranging from Burke to Carlyle) about the universal scope and ahistorical character of this type of language. In 1839 Davis emphasised the "the utter hopelessness of universalism" - an emphasis that certainly chimes with Berlin's account of the war between romantic particularism and enlightenment universalism, although criticisms of universal benevolence or cosmopolitan justice was a standard theme in enlightened discussions of politics from Adam Smith to Edmund Burke. ${ }^{109}$ While Davis preferred to base his claims for Irish independence on historical precedent rather than on natural right, tracing the "pedigree of our freedom" back to the Patriot Parliament of James II.110 As far as Davis was concerned, "the idea of 1782" - when Poyning's law was revoked and

\footnotetext{
108 See Dwan, The Great Community, 32-35.

109 Davis, Essays, 35.

110 For an analysis, see James Quinn, “Thomas Davis and the Patriot Parliament of 1689," in People, Politics and Power: Essays on Irish History 1660-1850, ed. James Kelly et al. (Dublin, 2009), 190-202.
} 
Irish parliamentary independence asserted - "is to be found full grown in 1689".111

Young Ireland's genealogies of freedom yielded its own share of "romantic history" in Ledwich's pejorative sense of the term. When discussing historical method, Davis advocated the use of archival evidence and a "philosophical eye", with the end of achieving "a genuine, not romantic likeness", but his own efforts and those of his peers fell considerably short of this. ${ }^{112}$ of course, the unevenness of these historical ventures partly stemmed from the attempt to base the claim for independence on largely historical grounds. As one Young Irelander admitted, "the history of Ireland can hardly in truth be called the history of a nation".113 The issue was compounded by the group's commitment to popular sovereignty: Young Ireland wanted a Parliament "congenial to the spirit of a People [. . .] chosen from the People, and by the People".114 But, according to James Fintan Lalor, a late entrant into the Young Ireland fold, no historical parliament had ever met these criteria - least, of all, the fetishized parliaments of 1689 or 1782.115 Thus, despite all their cavilling about erstwhile parliaments, the Young Irelanders heavily invested in the idea of a unitary people that was distinct from - because the legitimising condition - of all

\footnotetext{
111 Thomas Davis, The Patriot Parliament of 1689, ed. Charles Gavan Duffy (London, 1893), xciii. 112 Davis, Essays, 37, 38. For analysis of these historical efforts, see Quinn, Young Ireland and the Writing of Irish History.

113 Quoted in Charles Gavan Duffy, My Life in Two Hemispheres, 2 vols. (London, 1903), 2: 3.

${ }^{114}$ Nation, 23 September 1843.

115 James Fintan Lalor, Collected Writings, ed. L. Fogarty (Dublin, 1947), 59.
} 
parliamentary and governmental structures. This arguably explains the group's emphasis on the cultural "nation": it was a fraught attempt to give empirical substance to a juridical fiction - namely the people or nation as a constituent power.

Young Ireland's idea of a unitary nation or, indeed, people, was in many ways a fantasy, one that would reach particularly ludicrous proportions in the likes of Patrick Pearse ("The people will be lord and master. The people who wept in Gethsemane, who trod the sorrowful way, who died naked on a cross, who went down into hell, will rise again glorious and immortal, will sit on the right hand of God").116 Given Davis's own definition of the nation as a "spiritual essence" (a misquotation of Burke), it is easy to see why romantic nationalism is judged to have given a "metaphysical meaning" to the nation. ${ }^{117}$ There is, after all, a metaphysical aspect to the very title of Young Ireland's collection of verse - The Spirit of the Nation - although the phrase itself can be traced to Montesquieu (who Davis allegedly revered) as much as it might be attributed to later enthusiasts of national Geist. ${ }^{118}$ Joep Leerssen insists, nonetheless, that the nation became a "mystic, supra-individual, organic whole" under romanticism; its Irish high priests, he suggests, are Young Ireland.119 But the metaphysical

\footnotetext{
116 Patrick Pearse, Political Writings and Speeches (Cork, 2012), 271.

117 Leerssen, National Thought in Europe, 212.

118 Montesquieu, The Spirit of the Laws, trans. and ed. Anne M. Cohler, et al. (Cambridge, 1989), 310.

119 Joep Leerssen, “Anglo-Irish Patriotism and its European Context: Notes Towards a Reassessment," Eighteenth-Century Ireland, 3 (1988), 14.
} 
burden that the nation assumes under Young Ireland has as much to do with the issue of popular sovereignty as it has with the magic mist of romanticism. After all, sovereignty might not be a "mystical" concept (assuming we know what such descriptions mean), but it has repeatedly been cast as a fiction, albeit a useful one. ${ }^{120}$ According to the originator of the fictive theory, the sovereign was an artificial person, exceeding the empirical personalities of ruler and ruled.121 Indeed, the notion of a "people", for Hobbes, is equally artificial for prior to the construction of political authority it does not exist. ${ }^{122}$ Hobbes insisted that a people is the by-product of political association, never its legitimising condition, while advocates of popular sovereignty would invert the picture, casting the people as the ground of legitimacy. However, none of this made the "people" any less artificial or made up for the empirical deficit in some of our basic political concepts.

Stress on the peculiarly metaphysical or imaginary aspects of romantic nationalism, therefore, can easily downplay the role of non-empirical concepts in everyday political life. Young Ireland certainly circulated fictions of a unified people or nation and spoke with questionable presumption on its behalf, but a similar fiction (albeit one that acquires ontological weight through collective belief) underpins democratic government. Moreover, it is Young Ireland's

120 See Hent Kalmo and Quentin Skinner (eds.), Sovereignty in Fragments: The Past, Present and Future of a Contested Concept (Cambridge, 2010), 1-25.

121 Thomas Hobbes, Leviathan, ed. Richard Tuck (Cambridge, 1996), 111-15.

122 Thomas Hobbes, On the Citizen, ed. Richard Tuck and Michael Silverthorne (Cambridge, 1998), 95. 
nervous fascination with democracy, which repeatedly gets sidelined by disquisitions about its romantic politics. ${ }^{123}$ Not all Young Irelanders were committed democrats (Thomas Francis Meagher spurned equality and endorsed a mixed constitution), but some of the key ideologues of the movement - Dillon, Davis and Duffy, for instance - were convinced that democracy was the political future awaiting Europe. As the Nation put it in 1843, "the principle of rational democracy is advancing in every land". ${ }^{124}$ O'Connell's extraordinary experiment in mass mobilisation seemed to have struck many contemporaries as a democratic dawn, but it also stoked ancient misgivings about popular rule. Writers on the Dublin University Magazine, for instance, presented it as an intrinsically factitious form of politics that cast the many against the few - a particularly worrying prospect in Ireland where huge economic disparities were accompanied by religious differences. ${ }^{125}$

The Young Irelanders were not entirely immune to these fears, and worked hard to construct a common sense of Irishness that would transcend differences of creed and class. Indeed, Davis even nursed hopes of uniting Orange and Green under a common banner: "Ireland! Rejoice, and England! deplore - / Faction and feud are passing away". But under these mawkish incitements to unity lurked

123 For a rare if brief discussion of their attitudes to democracy, see Laurent Colantonio, “Democracy and the Irish People, 1830-48," in Re-imagining Democracy in the Age of Revolutions: America, France, Britain, Ireland 1750-1850 (Oxford, 2013), 170-72.

124 The Nation, 5 August 1843.

125 "In Ireland, alone the more democratic its political predilections are found to be, the more undisguised its religious intolerance." Dublin University Magazine, 11 (April, 1838), 526. 
more subtle concerns about the fate of the social bond under democracy. ${ }^{126}$ Equality, as Tocqueville had argued, eroded hierarchical forms of solidarity built on deference and noblesse oblige, but it did little in itself to produce alternative forms of fellowship. The result was "individualism" - a blinkered preoccupation with private concerns at the expense of the public freedom upon which all personal liberties depended. Davis, a keen reader of Tocqueville, outlined the problem in apocalyptic terms: "on the shore of democracy is a monstrous danger - the violence and forwardness of selfish men, regardful only of physical comfort, ready to sacrifice to it all sentiments - the generous, the pious, the just . . . till general corruption, anarchy, despotism, and moral darkness shall re-barbarise the earth."127 For this reason, Davis placed a strong emphasis on public education - a necessary curb to irrational self-interest or individualism - and stressed the solidarity that was to be derived from a shared culture. The result may have been a very culturally-orientated nationalism, but it had a profoundly political origin.

The group's attacks on individualism went hand in hand with its campaign against utilitarianism, with Jeremy Bentham crudely cast as an apologist of selfishness. Indeed, the Nation brought a long list of charges against Bentham: that he was a reductive rationalist, tone-deaf to sentiment; that he was hedonist who ignored the higher goods of artistic and moral experience; that his naïve universalism made him insensitive to history; that he consequently had no sense of how "national character" might legitimately shape law and politics. Arguably,

126 Davis, Poems, 30-32. The Nation, 12 October 1844.

127 Davis, Essays, 45. 
it is in their resistance to Benthamism that Young Ireland most closely aligned themselves with the stereotype of a romantic school of politics. ${ }^{128}$ But it is also worth noting that it is a stereotype that utilitarians helped to inaugurate - most obviously in John Stuart Mill's famous juxtaposition of the schools of Bentham and Coleridge ("every Englishman of the present day is by implication either a Benthamite or a Coleridgian"). ${ }^{129}$ The Nation provided a long account of Mill's two essays, clearly opting for the school of Coleridge, whilst simultaneously declaring itself indifferent to a foreign quarrel. But if this affiliation was romantic, then it was a stance shared in part by Carlyle (whose hatred of Benthamism is well known), with Macaulay (whose attacks on James Mill were only matched in their ferocity by his dismissals of the romantic Southey) and even with J. S. Mill (who publicly rebuked Bentham's insensitivity to history, national character, and higher pleasures). ${ }^{130}$ Like the Young England Party - or more famously Dickens - the Young Irelanders also associated Benthamism with the harsher aspects of political economy, although up to the Famine they were as sceptical of state-sponsored welfare programmes as any card-carrying Benthamite. Indeed, for all their anti-Benthamite bluster, the group's emphasis

\footnotetext{
${ }^{128}$ For an account of the rivalry between romantics and utilitarians, see Donald Winch, Wealth and Life: Essays on the Intellectual History of Political Economy in Britain, 1848-1914 (Cambridge, 2009).

${ }^{129}$ John Stuart Mill, Collected Works of John Stuart Mill. Volume X: Essays on Ethics, Religion and Society, ed. J. M. Robson (Toronto, 1985), 121.

${ }^{130}$ Nation, 29 October 1842.
} 
on self-help, educational reform and social progress, have been cast as broadly utilitarian. ${ }^{131}$

Romanticism, therefore, has little explanatory value when it comes to accounting for the alleged prototype or origin of romantic nationalism in Ireland. Of course, some aspects of Young Ireland's political vision could be called "romantic" in a loosely evaluative sense, although the reasons for this have more to do with problems internal to their republicanism than with the particular lustre of romanticism as an ideology. Young Ireland's vision of citizenship could certainly seem naïve in a modern context. Modern states, after all, were large, centralised and representative; warfare was technologically sophisticated and increasingly left to professional armies; political economy - repeatedly denounced by Mitchel as an "English" gospel even as he attempted to sponsor an "Irish" version - was in crucial respects the new science of government and it demanded a type of expertise not easily acquired by all. ${ }^{132}$ In fact, the most basic principles of modern social organisation - namely, the specialisation and delegation of function - could make the ethos of the citizen-soldier seem sadly out of date.

Young Ireland worked hard to convert their republican ideals into a practical reality: they sponsored a policy of de-centralisation and local government; they stressed both the civic and economic value of national education; more hopefully, they also made bids for the revival of a militia. But much of this zeal

\footnotetext{
${ }^{131}$ See Foster, Modern Ireland, 311; also Helen O'Connell, Ireland and the Fiction of Improvement (Oxford, 2006),163.

${ }^{132}$ John Mitchel, The Last Conquest of Ireland (Perhaps), ed. Patrick Maume (Dublin, 2005), 107.
} 
culminated in a bellicose rhetoric that could seem like a flight from politics rather than an expression of citizenship - an interpretation arguably confirmed rather than challenged by the group's risible rebellion in $1848 . \quad$ If, as Justin McCarthy averred, the Young Irelanders embarked on a rising in order to convince others they were not mere "romancists" pledged to a "poetic dream", it merely confirmed to many that they were dangerous political fantasists. ${ }^{133}$

Young Ireland, however, had a profound influence on the development of modern Irish nationalism. As Owen McGee has argued, the IRB derived much of its political ideology from the Young Irelanders, sharing their emphasis on democracy, republican citizenship and martial valour. ${ }^{134}$ Moreover, Fenians such as John O'Leary championed Young Ireland's commitment to civic education and cultural endeavour. ${ }^{135}$ Arthur Griffith was an ardent Young Irelander. As Patrick Maume has shown, much of his republican programme from his emphasis on personal and collective independence to his proposals for economic self-help were self-consciously traced to Davis and Mitchel. ${ }^{136}$ Patrick Pearse also paid homage to Davis, crediting him with the invention of a

133 Justin McCarthy, An Irishman's Story (London, 1904), 79.

134 Owen McGee, The IRB: The Irish Republican Brotherhood from the Land League to Sinn Féin (Dublin, 2005). But personal relations between the two groups were often fractious. See James Quinn, "The IRB and Young Ireland: Varieties of Tension," in The Black Hand of Republicanism: Fenianism in Modern Context (Dublin, 2009), 3-17.

135 See, in particular, Matthew Kelly, The Fenian Ideal and Irish Nationalism, 1882-1916 (Woodbridge, 2006).

136 Patrick Maume, 'Young Ireland, Arthur Griffith, and Republican Ideology: The Question of Continuity, Eire-Ireland, 34.2 (1999), pp. 155-74. 
"spiritual" nationalism which he distinguished from the "political" nationalism of Wolfe Tone. ${ }^{137}$ Though Pearse would ultimately claim that these nationalisms were co-dependent, the very terms of the distinction evacuated the political content of Davis's beliefs. Historians who stress the "romantic" or "cultural" features of Young Ireland's nationalism at the expense of its political substance practice a similarly dubious abstraction. ${ }^{138}$

\section{The Romantic Zombie}

Throughout the twentieth century several post-mortems on "Romantic Ireland" would be produced. In 1911 George Moore put the case with characteristic force: "We are supposed to be a most romantic and adventurous race, and very likely we were centuries ago; but we are now the smuggest and the most prosaic people in the world."139 Yeats too proclaimed his disenchantment. As he put it in his famous patriotic ubi sunt, "Romantic Ireland's dead and gone / It's with O'Leary in the grave."140 The death of the old Fenian in 1907 augured the end of a republican tradition of martial valour and public service. Ireland was now a disenchanted island, characterised by commerce, selfishness, and moral triviality. The demise of "Romantic Ireland" may have been a cliché about a

\footnotetext{
137 Pearse, Political Writings, 238-39.

138 See, in particular, MacDonagh, The Emancipist, 28; Boyce, Irish Nationalism, 169.

139 George Moore, Hail and Farewell, 3 vols. (London, 1911-14), 2: 313.

140 Yeats, Poems, 289.
} 
cliché (Moore, as we have seen, had rued the disappearance of an Ossianic idyll from about 1808), but it clearly illustrates how nationalism was conceived as a "romantic" ethos even by its alleged adherents. This would also become an entrenched historiographical perception of nationalism in twentieth-century Ireland.

For some, of course, "Romantic Ireland" could not die fast enough. The journalist, D. P. Moran, for instance, was an ostentatiously anti-romantic figure, rejecting all appeals "to passion and high falutin' sentiment", whilst selfpurportedly honouring "reason" and "commonsense". ${ }^{141}$ He roundly rejected the tropes that had traditionally described Irish virtue - idealism, sentimentalism and chivalry - in the name of "enlightened patriotism". His use of Burke in this context was instructive: Irish people needed to remember that the days of chivalry were over. Rebel "clap-trap" about fighting for Ireland overlooked the specialised nature and technological sophistication of modern warfare the Young Irelanders were duly dismissed as "large-hearted well intentioned fools"). ${ }^{142}$ The pursuit of "heroic politics" in Ireland had led to a disastrous neglect of economic science. As Moran put it, "the age of economics has come" and the heroic virtues of the zōon politikon had been supplanted by the more modest albeit more sustainable talents of homo economicus (indeed "politics" is often a bad word in Moran's lexicon). ${ }^{143}$ According to Moran, however, these social facts were lost on Ireland's fighting men.

\footnotetext{
${ }^{141}$ D. P. Moran, The Philosophy of Irish Ireland, ed. Patrick Maume (Dublin, 2006), 83.

142 ibid., $19,40$.

143 ibid., 15 .
} 
But fighting Ireland would not go away. Indeed, given the militarisation of Irish politics between 1913 and 1923 - much of which took place alongside the mass bloodletting of the Great War - it was Moran's position which could look anachronistic. Under the Irish Volunteers the republican ideal of the citizensoldier would be revived. According to its founding manifesto, Irish citizens had an inherent right to bear arms in the name of "National and Individual Liberty [and] Manly Citizenship."144 Matthew Kelly rightly asserts that the language of civic republicanism provided a thin veneer of coherence to an otherwise very heterogeneous movement, but all its staple motifs - from the critique of dependency and public slavery to the exaltation of martial valour and public service - were widely broadcast. ${ }^{145}$

The language of sacrifice deployed by the revolutionaries of 1916 looks less eccentric - if no more appealing - when placed in the broader context of the Irish Volunteers and, indeed, the World War I - a setting in which ideas of service, sacrifice, and bloodshed became thoroughly banalised. Unsurprisingly, figures like Patrick Pearse rejoiced in the "rediscovered citizenship" of the Volunteers. ${ }^{146}$ After all, the citizen who could not vindicate his citizenship through arms was a contradiction in terms. "A citizen without arms", he opined, "is like a priest

\footnotetext{
${ }^{144}$ See F. X. Martin (ed.), The Irish Volunteers, 1913-1915 (Dublin, 1963), 101.

145 Matthew Kelly, “The Irish Volunteers: a Machiavellian moment?," in The Ulster Crisis: 18851921, ed. D. George Boyce and Alan O’Day, (London, 2005), 64-85, 64.

146 Pearse, Political Writings and Speeches, 66.
} 
without religion, a woman without chastity, like a man without manhood."147 Pearse's adulation of arms and his confidence in the redemptive value of bloodsacrifice developed a strange intensity (only outdone, perhaps, by MacSwiney's "Ode to a Bullet"), but this should not preclude recognition of the ways in which the Rising - and Pearse himself - was a product of Volunteer ideology and not just some romantic Weltanschauung.

But from the start the Rising would be viewed as a quintessentially "romantic" gesture. According to George Bernard Shaw, the Rising was a "harebrained romantic adventure."148 Yeats was stunned by its "heroic lunacy", but he also felt that it had made the phrase "Romantic Ireland's dead and gone" appear oldfashioned. ${ }^{149}$ A similar sense of a resurgent romanticism would shape historiographical interpretations of the event. For F. S. L. Lyons, the men of 1916 were "all romantic revolutionaries cast in the same fanatical mould"; for others, they were "militants steeped in romantic nationalism".150 Tom Garvin attempted to put this "political romanticism" within a European context, while Seán Farrell Moran also claimed that figures like Pearse were part of a broader "European

\footnotetext{
147 ibid., 155.
}

148 George Bernard Shaw, John Bull's Other Island , How he Lied to Her (London, 1931), 65.

149 Yeats to Lady Gregory, 9 May 1916, Collected Letters, Oxford University Press, (InteLex Electronic Edition), 2002; Yeats, Poems, 820.

150 F. S. L. Lyons, "The Revolution in Train, 1914-1916”, A New History of Ireland. Volume VI: Ireland Under the Union, 1870-1921 (Oxford, 1989), 19 ; Liam Kennedy, "Was there an Irish War of Independence?," in Hearts and Minds: Irish Culture and Society Under the Act of Union, ed. Bruce Stewart (Gerrards Cross, 2002), 212. 
Revolt against Reason".151 Recent historiography questions the centrality given to Pearse as an ideologue of the Rising, arguing that it neutralises the heterogeneous constitution and motivational diversity of a complex event.152 Moreover, when attempting to recover the motivations behind the Rising, historians now tend to assume that its main participants were rational agents with an intelligible structure of belief. ${ }^{153}$ Yet rationalisations of their irrationality - namely their "romantic" dispositions - continue. ${ }^{154}$

The romanticism of the Rising is also related to its literary qualities - with the "literary" ambiguously cast as the motivation for the event, but also as a metaphor for its impractical character. ${ }^{155}$ Pearse the playwright and poet assumes a prominent role in this interpretation as do other poet-revolutionaries such as Thomas MacDonagh, and Joseph Plunkett. Yeats has also been cast as a fomenter of bloodshed. There was, perhaps, a certain vainglory behind the poet's sense of culpability with regard to 1916. Nonetheless, his belated and very public self-questioning about the possible effects of Cathleen Ni Houlihan

151 Tom Garvin, Nationalist Revolutionaries, 1858-1928 (Oxford, 1987), chapt. 1; Seán Farrell Moran, "Patrick Pearse and the European Revolt against Reason."

152 Fearghal McGarry, The Rising. Ireland: Easter 1916 (Oxford, 2010), 96.

153 For an analysis of some of these "perfectly rational" beliefs, see McGarry, The Rising, 100-101.

See too Hart, The I.R.A. at War, 107. On the complex motivations of Irish revolutionaries, see Roy Foster, Vivid Faces: The Revolutionary Generation in Ireland (London, 2014).

154 See Dingley, The IRA, 62; idem., Durkheim and National Identity, 144.

155 The most committed account of its literary origins and nature remains W. I. Thompson's, The Imagination of an Insurrection: Dublin, 1916 (New York, 1967). But see too, Charles Townshend, Easter 1916 (London, 2005), 15-17. 
("Did that play of mine send out/ Certain men the English shot?") has been taken seriously by historians - most notably by Conor Cruise O'Brien. ${ }^{156}$ In 1967 O'Brien insisted that there could be "no sure answer to the question that troubled Yeats on his deathbed."157 But in 1975 he seemed more resolved: the "probable answer to Yeats's question was 'yes, it did"' send men out to meet the British.158 In 1985 0’Brien was a certain man: "I believe, not only that it did, but that it is still sending them out."159 The context for this hardening of attitude was clearly the troubles in the North of Ireland - a conflict in which O'Brien adopted a strongly anti-republican position.

Back in 1948 0'Brien seemed to be relatively pleased with the fact that Ireland was "the least romantic and the least revolutionary of countries" - an impression echoed by his friend Seán Ó Faoláin. ${ }^{160}$ According to Ó Faoláin, the profound disenchantment of the Irish Civil War, had woken the country from "the mesmerism of the romantic dream". ${ }^{161}$ of course, some found life without enchantment a little trying. In 1933 - a year into De Valera's long and largely

\footnotetext{
156 W. B. Yeats, "The Man and the Echo," in Poems, 632. Charles Townshend also avers that the play's “impact is hard to exaggerate”. Charles Townshend, Easter 1916: The Irish Rebellion (London, 2005), 16.

157 Conor Cruise O’Brien, “Two-Faced Cathleen,” New York Review of Books, 29 June 1967.

158 The Irish Times, 22 August 1975.

159 The Times, 28 January 1989. For a fuller account of this trajectory, see Diarmuid Whelan, Conor Cruise O'Brien: Violent Notions (Dublin, 2009), 112-14.

160 Conor Cruise O’Brien, Maria Cross (Oxford, 1952), 111.

161 The Bell, 2.1 (April, 1941), 11. Ireland, had finally "ceased to be a romantic island." Sean O’Faolain, The Irish, rev. ed. (London, 1969), 142.
} 
peaceable reign - George Russell noted: "We have passed out of the romantic phase of Irish nationalism now and are concerned about dull matters like tariffs. I am glad I was born in romantic Ireland. It is a little dull today compared with twenty five years ago."162 But both O’Brien and Ó Faoláin seemed pleased that Ireland had succumbed to ordinariness. Yeats's post-mortem of 1913 was, perhaps, premature, but Ó Faoláin could declare with some confidence in 1941 that "Romantic Ireland's dead and gone."163

Events in the North in the 1960s and 70s, however, produced a radical readjustment of positions. The romance of violence had returned and figures like Conor Cruise O'Brien shrank back in horror. O’Brien became convinced that "romanticism favours the IRA" and he roundly condemned the characteristic features of this delirium: emotivism, aestheticism and anti-rationalism. ${ }^{164} \mathrm{He}$ also emphasised its fascist orientation. According to Thomas Mann's influential interpretation, "German Romanticism broke out into a hysterical barbarism" under Hitler. ${ }^{165}$ Theorists of nationalism, such as Hans Kohn, duly traced the credo's most extreme manifestations to romanticism. ${ }^{166}$ For Kedourie, too, the "nihilistic frenzy of Nazism" had a romantic source, while Berlin, would also

162 Cited in Garvin, Nationalist Revolutionaries, 169.

163 The Bell, 2.1 (April, 1941), 11.

164 The Irish Times, 29 March 1979.

165 Thomas Mann, Addresses Delivered at the Library of Congress, 1942-49 (Washington DC, 1963), 64.

166 See Hans Kohn, The Idea of Nationalism, 349-93, idem, "Romanticism and the Rise of German Nationalism," The Review of Politics, 12.4 (1950), 443-72. For a re-articulation of Kohn's thesis, see Liah Greenfeld, Nationalism: Five Roads to Modernity (Cambridge Mass., 1992), 322-52 
confirm that "Fascism owes something to Romanticism".167 O’Brien, therefore, was in good company when he proclaimed in 1975 that "romanticism [. . .] in politics tends in the direction of fascism". ${ }^{168}$ The aestheticisation of politics now central to the definition of romanticism and fascism - was, 0'Brien feared, a dangerous tendency of Irish political life. ${ }^{169}$

Yet, prior to 1975, 0'Brien had repeatedly questioned the viability and desirability of a dividing-line between aesthetic and political spheres of value. In this context, he would cite his beloved Edmund Burke: "Art is man's nature".170 Like Burke, O'Brien seemed to think that the imagination was constitutive of moral understanding: ostensibly, it projected values onto facts and imposed a decent drapery on our otherwise naked, shivering natures. To abstract imagination from politics was thus to destroy the moral basis of governance. In these contexts, he was happy to declare the human being a "myth-making animal". 171 But in an Irish domain he recommended the retirement of myth,

167 Kedourie, Nationalism, 82; Berlin, Roots of Romanticism, 167-68. Also Isaiah Berlin, The Crooked Timber of Mankind: Chapters in the History of Ideas, ed. Henry Hardy (London, 2003), 202.

168 Conor O’Brien, “An Unhealthy Intersection,” New Review, 2.16 (1975), 3-8. Republished in The Irish Times, 21 \& 22 August, 1975.

${ }^{169}$ See Conor Cruise O’Brien, Religion and Politics (Coleraine, 1984), 9.

170 Conor Cruise O’Brien \& William Dean Vanech, Power and Consciousness (London, 1969), 214. The quote is from "The Appeal from the New to the Old Whigs" (1791). See Edmund Burke, The Works of the Right Honourable Edmund Burke, 8 vols. (London, 1854-89), 3: 86.

171 O’Brien, Power and Consciousness, 211. 
although even here he questioned both the possibility and desirability of a thoroughly disenchanted politics. ${ }^{172}$

O'Brien's denunciation of romance in Ireland - essentially, an inversion of Yeats's position - would prove highly influential. Subsequent interpreters, for instance, have traced paramilitary violence to different kinds of romanticism. In a Festschrift for O’Brien, for instance, Richard English argued that the "devious Romanticism of Percy Bysse Shelley" stood behind the activities of Irish nationalists - an assessment that also owes something to Frank 0'Connor (noting the glorification of death in Shelley and Meredith, O'Connor wondered in his autobiography "if there was not some relationship between Irish nationalism and the Romantic movement"). ${ }^{173}$ In English's later work the IRA of the War of Independence and Civil War remain "Shelleyan Revolutionaries" - evidenced in their cult of self-sacrifice, their exaltation of the passions and their fundamental impracticality (what made the "IRA dream unrealistic also made it so appealing").174 English has arguably done more than almost any other living scholar to challenge perceptions of the IRA as mindless killers indifferent to reason or rational justification. ${ }^{175}$ Moreover, he is keen to stress the ideological complexity of nationalism. Yet the project is ill served by attempts - however

\footnotetext{
172 The Irish Times, 22 August 1975.

173 Richard English and Joseph Morrison Skelly, Ideas Matter: Essays in Honour of Conor Cruise O’Brien (Dublin, 1998), 14. See Frank O'Connor, An Only Child and My Father's Son (London, 2005), 176.

174 English, Irish Freedom, 303.

175 See, in particular Richard English, Armed Struggle: A History of the IRA (London, 2003).
} 
localised - to organise a political psychology around a received caricature of romanticism.

The activities of the IRA and indeed nationalism more broadly continue to be read through highly polarised accounts of romanticism and enlightenment sometimes organised around very sectarian lines. According to a recent interpretation, for instance, Irish history is characterised by two mind-sets: "a Protestant Unionist one based on science and a Catholic Nationalist one based on Romantic feeling".176 Such verdicts yield a familiar portrait of romantic psychology: emotions severed from reason, a fevered imagination deprived of all discernment, and a sentimentalised commitment to violence (for the Herderians of Ballymurphy, "the very philosophy of Romanticism legitimized violence, especially at its most volkisch"). ${ }^{177}$ If these discussions of romanticism run strangely parallel with earlier discourses about national character, then 0'Brien was more explicit than most about the connection. The politics of illusion, he insisted, "derived from a culture which has long placed little value on rationality - a word which Irish printers almost automatically misprint as the more familiar term nationality."178 Here O'Brien capitulated to the type of cliché he spent much of his life exploding.

\footnotetext{
176 Dingley, Durkheim and National Identity in Ireland, 144.

177 Dingley, The IRA, 12.

${ }^{178}$ Conor Cruise O'Brien, Herod: Reflections on Political Violence (London, 1978), 47. Ironically, in O'Brien's autobiography - produced in London - a similar misprint occurs: Lecky is judged to have written a history of "nationalism" not "rationalism". Conor Cruise 0’Brien, Memoir: My Life and Themes (London, 1998), 7.
} 
O’Brien's tendency to see nothing but atavism, emotivism, and irrationality in nationalism is understandable, particularly in the polemical contexts of his time. But, according to recent assessments, this outlook compromised his understanding of the conflict in Northern Ireland and distracted him from its political basis. ${ }^{179}$ Moreover, it also sustained a dubious historiography, organised around false genealogies, schematic oppositions and a crude psychology. If the enabling premise of intellectual history is the rationality of the practices it aims to describe, then all too often the historiography of romantic nationalism has disabled understanding before inquiry has properly begun. ${ }^{180}$ The term "romantic" may be intelligibly used as an evaluative principle in the context of nationalism. As I have argued, it has always operated thus, serving as a highly charged metaphor in numerous polemical contexts. However, partly due to this polemical history, the concept's explanatory power is constrained. Converted into a world-view or cultural doctrine for the purpose of political explanation, the concept of "romanticism" produces illusions it professes to diagnose.

\footnotetext{
${ }^{179}$ See Mark McNally, “Conor Cruise O’Brien's Conservative Anti-Nationalism," European Journal of Political History, 7.3 (2008), 308-330; Richard Bourke, "Languages of Conflict and the Northern Ireland Troubles" The Journal of Modern History, 83.3 (2011), 544-78. See also Whelan, Conor Cruise O'Brien, 152-72.

${ }^{180}$ According to Skinner's "golden rule," the historians must begin by making historical beliefs appear "as rational as possible". Skinner, Visions of Politics, 1: 54.
} 
